\title{
AN ANALYSIS OF THE FACTORS CONTRIBUTING TO ELEPHANT POPULATION FLUCTUATIONS IN SWRA USING RANGER-BASED KNOWLEDGE AND PERCEPTIONS
}

\author{
Mahakata Innocent ${ }^{1}$ and Mapaure Isaac ${ }^{2}$ \\ ${ }^{1}$ Ecologist, Branch of Terrestrial Ecology, Sengwa Wildlife Research Institute, Bag 6002 \\ Gokwe, Sebungwe, Zimbabwe Parks and Wildlife Management Authority \\ Email: innocentmahakata@gmail.com \\ ${ }^{2}$ Department of Biological Sciences, University of Namibia, P. Bag 13301, Windhoek, \\ Namibia.
}

Cite this article:

Mahakata I., Mapaure I. (2021), An Analysis of the Factors Contributing to Elephant Population Fluctuations in SWRA using Ranger-based Knowledge and Perceptions. African Journal of Environment and Natural Science Research 4(4), 43-60. DOI: 10.52589/AJENSRB82VM7BP.

\section{Manuscript History}

Received: 20 June 2021

Accepted: 28 July 2021

Published: 3 Oct 2021

Copyright $\odot 2020$ The Author(s). This is an Open Access article distributed under the terms of Creative Commons AttributionNonCommercial-NoDerivatives 4.0 International (CC BY-NC-ND 4.0 ), which permits anyone to share, use, reproduce and redistribute in any medium, provided the original author and source are credited.
ABSTRACT: This study aimed at examining local ranger-based knowledge and perceptions on explaining contributing factors to variations on elephant fluctuations seasonally and over a long period in Sengwa Wildlife Research Area following a massive decline of elephants by nearly $76 \%$ after the 2014 National Aerial Survey done in Sebungwe Region, Zimbabwe. Data were collected between $1^{\text {st }}$ and $20^{\text {th }}$ August 2020 using a purposive sampling approach administered to questionnaire to resident SWRA rangers $(n=25)$. Our results show that rangers considered a combination of factors that may have affected elephant fluctuations in SWRA including poaching, migration, settlement and impact of climate change. However, our results suggest that rangers had inadequate knowledge about elephant migration destinations. Moreover, mixed perceptions about the impact of trophy hunting, poaching and climate change-induced factors were recorded from the participants. The results contribute to a growing understanding of poaching, climate change, trophy hunting and human settlement on elephant behaviour. The study recommends improvement in elephant monitoring through investments in elephant collars and radio tracking to better understand elephant daily and seasonal dispersal movements.

KEYWORDS: Climate change, aerial survey, human activities, migration, poaching, settlements, Sengwa Wildlife Research Area (SWRA), surface water, trophy hunting. 


\section{INTRODUCTION}

Factors that affect elephant distribution at fine-scale are well known. Primary drivers are associated with food and water availability (Chamaillé and Fritz, 2007), with the presence of humans as an additional factor (Mpakairi et al., 2019). Understanding the key factors that influence the potential dynamics of elephants in changing landscapes of Sengwa Wildlife Research Area (SWRA) has been at the centre of enquiry in wildlife conservation for many decades because of their importance to the ecosystem functioning and impact of human activities on its habitat (Mpakairi et al., 2019). Understanding the dynamics is particularly important for African elephants (Loxodonta africana) whose population indicated a significant decline by approximately 76\% over the year from 2002 to 2014 (Dunham et al.,2015).

Large herbivores aerial survey was conducted in SWRA and other elephant range areas in Zimbabwe from July-September 2014. The survey was part of a national census of the African elephants in Zimbabwe (Dunham and Mackie, 2002). The survey objective was to monitor trends in large herbivore populations in different areas across Zimbabwe. SWRA is part of the Sebungwe region consisting of a mosaic of Parks and Wildlife estate and communal areas. The SWRA area previously had a physical barrier to restrict wildlife movement into the communal areas before it was illegally removed. The whole of Sebungwe Region also has no physical boundary and thus, large herbivores are able to travel to other areas such as the Hwange National Park (HNP) or Zambezi valley areas (Dunham et al. 2015). In 2014, part of the SWRA was degazzetted following the promulgation of Statutory Instrument 47 of 2014 resulting in approximately $50 \mathrm{~km}^{2}$ of the area parcelled out for human settlement. Intense human settlement and clearance of natural vegetation for agriculture and wanton harvesting of wildlife resources on the periphery of the protected areas were experienced (Dunham et al., 2015; Chinoitezvi, 2017) This resulted in the reduction of wildlife habitats, thus affecting the survival of wildlife species such as elephants (Mpakairi et al., 2019).

The aerial survey of 2014 revealed a large decline of elephants in Chirisa and SWRA by nearly 76\% since 2001(Dunham et al., 2015). However, to account for the losses, the elephant all carcass 'ratio' (Hamilton and Burrill, 1991) observed during the survey (density of $0.003 \mathrm{~km}^{2}$ ) could not reveal enough evidence to account for the missing elephants in the SWRA even though it was higher compared to 2001 ratio. The total effort for SWRA in the 2014 survey was 15 (Dunham et al., 2015).

This study aimed to determine possible factors leading to elephant population declines in the SWRA using the knowledge and perceptions of Park Rangers about the dynamics of SWRA elephants over years. No previous research has focused explicitly on Ranger-based knowledge and perceptions about fluctuations in elephant populations, especially given the emerging conservation challenges where elephant populations are considered to be dwindling rapidly in the Sebungwe region and elsewhere in Zimbabwe. Hence the main objective of this research was to gather baseline knowledge and perceptions of Rangers concerning the possible factors responsible for the fluctuations and declines in elephant populations in SWRA over the last several years and suggest ways to maintain a good elephant population. 


\section{METHODOLOGY}

\section{Study Area}

The SWRA is situated in the southern end of the Chirisa Safari Area (CSA), Zimbabwe $\left(18^{0} 10^{\prime} \mathrm{S} ; 28^{0} 15^{\prime} \mathrm{E}\right.$, Figure 1$)$. It covers an area of $373 \mathrm{~km}^{2}$. The SWRA is separated from the surrounding communal lands on the south, east and west by a clear road with no physical barrier and in some areas, over-populated, also families live within $200 \mathrm{~m}$ of the boundary. Encroachment into the buffer zone occurs. A well-defined scarp running northeast/southwest divides the area into two levels. The altitude varies from about $800 \mathrm{~m}$ to $1037 \mathrm{~m}$. Three major rivers, Sengwa, Manyoni and Lutope dissect the sandstone escarpment. The vegetation is generally described as deciduous miombo savanna woodlands on the upper sandy soils and dry early deciduous savanna woodlands dominated by Colophospermum mopane on the lower heavier soils (Taylor, 1991). Broad vegetation types are shown in Figure 1 below.
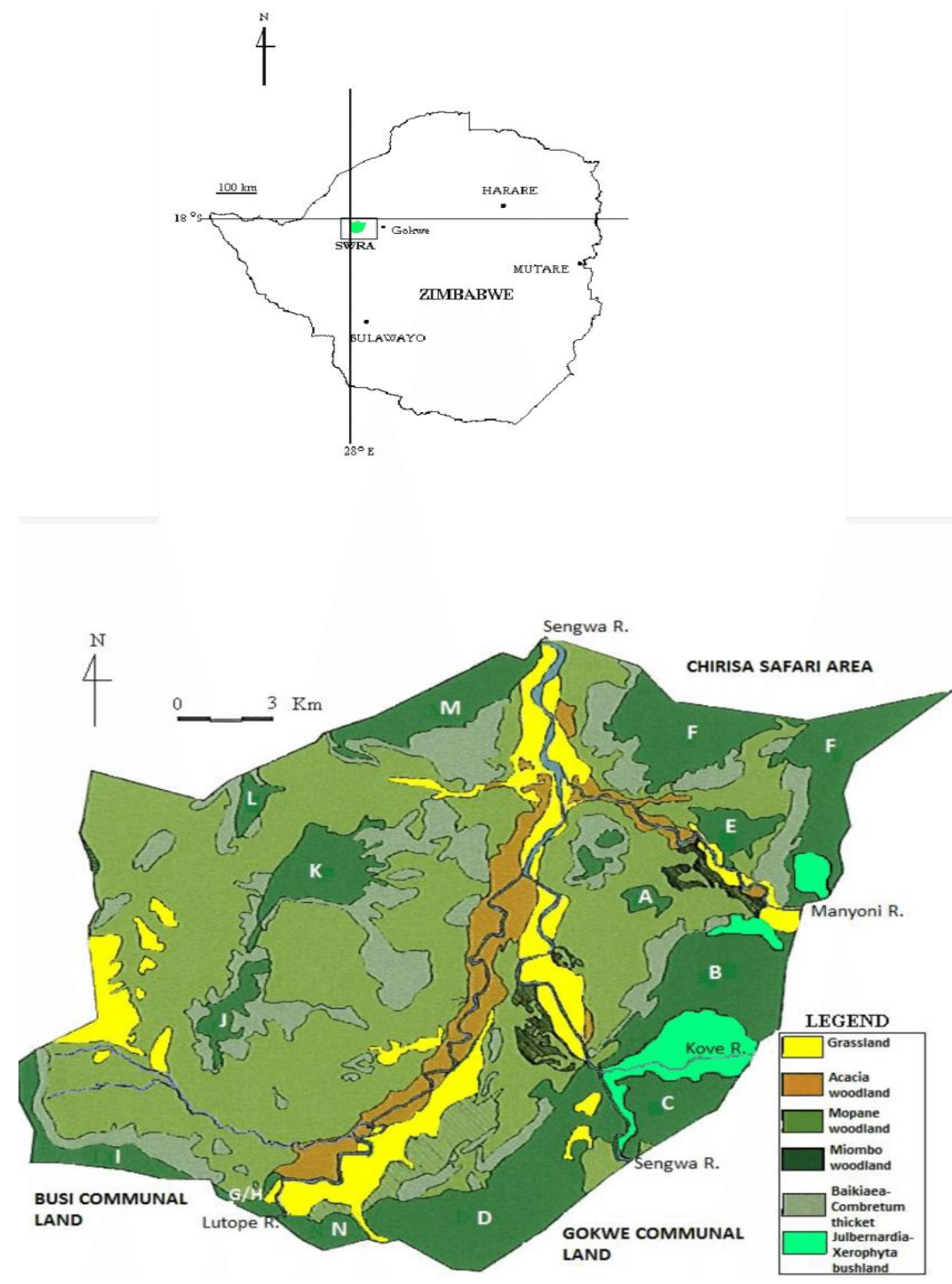

Figure 1: Map showing the location of SWRA and vegetation map showing different vegetation types found in the study area (Source: Mapaure, 2001). 
Three seasons are experienced: a hot wet (November to April), a cool dry (May to July) and a hot dry (August to October) season. The mean annual rainfall for the past 55 seasons measured in the area is $612 \mathrm{~mm}$ (Mahakata, 2020). The rainfall patterns for the period from 1965 to 2019 is shown in Fig. 4. The mean annual temperature is $22.2^{\circ} \mathrm{C}$ and the highest temperatures occur in October and the lowest in July (Mhiripiri and Mlambo, 2021).

The SWRA has a diversity of large mammal communities of seven species of carnivores and 18 species of large herbivores (Guy, 1989). The elephant population, which exceeded the carrying capacity since 1965 is currently hovering above the density of 2 elephants $/ \mathrm{km}^{2}$ but is recommended to be stabilised at about 250 animals (Figure. 2). The first major reduction (through culling) in elephant numbers took place around 1975, then an $82 \%$ reduction between 1980 and 1982 followed by a 60\% reduction in 1992(Mapaure and Campbell, 2002).

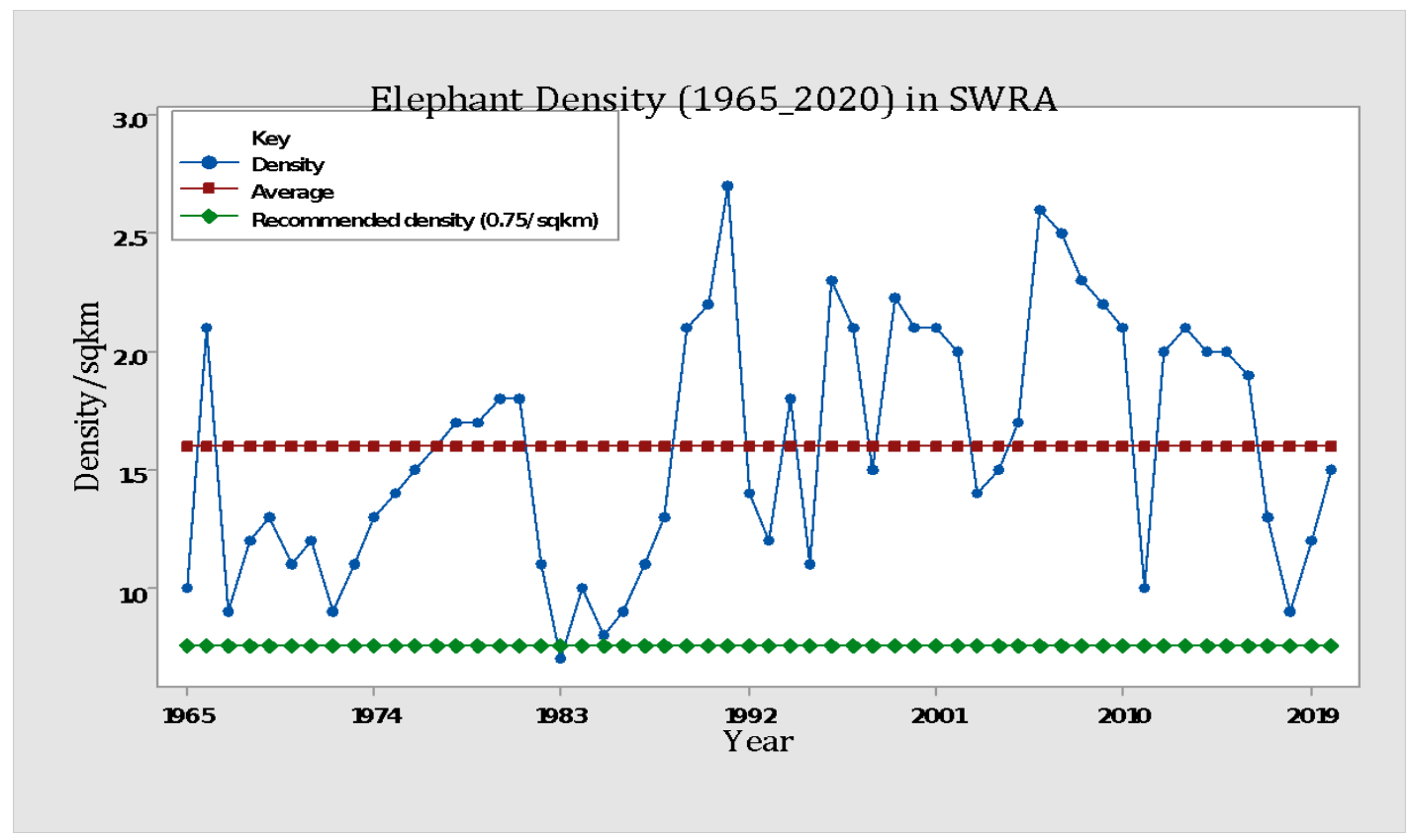

Figure 2: Trends in elephant density in SWRA from 1965 to 2020 based on data obtained from ground transect surveys. (Source: SWRI unpublished Elephant data).

\section{Data Collection and Analysis}

Purposive sampling was used to select Rangers based on the years a participant stayed at SWRI. Rangers who stayed at least 10 years were selected including current and former Rangers who may have been transferred elsewhere. Each Ranger was given an open-ended questionnaire to fill. A total of 25 participants were selected based on their historic experience with elephant fluctuations in SWRA. The questionnaire included both open-ended and fixed response questions. The questionnaire was designed to evaluate their knowledge of previous and current elephant status and suggest major drivers of population dynamics over time. Pre-testing of the questionnaire was undertaken at CSA where five Rangers were selected and given a sample questionnaire to fill and later give comments on the quality of the questionnaire and adjustments were made. All the questionnaires were electronically administered by the resident Ecologist to the transferred staff while current staff were served with hard copies. The survey 
was conducted from $1^{\text {st }}$ to $20^{\text {th }}$ August 2020 . The respondents were given one week to complete the questionnaire.

Data were grouped and summed by response category. A qualitative method was used to analyse the data after categorisation and unitising. Where multiple responses were possible on an open-response question, data were presented as the percentage (\%) of respondents giving each response.

\section{FINDINGS}

\section{Rangers' knowledge and perceptions on elephant population trends}

A high proportion $(80 \%)$ of respondents largely $(n=25)$ showed that poaching, migration and trophy hunting were the main contributors to elephant population reductions between 2009 and 2016. Surface water availability and an increase in severe droughts in recent years were resulting in the drying up of springs, forage shortage were all attributed to climate change impacts. Human settlements in buffer zones and along the hard edge and degazettement of part of SWRA under Statutory Instrument 147 of 2014 were other factors raised (Table 1 below).

Table 1: Ranger-based perceptions on the causes of elephant dynamics in SWRA.

\begin{tabular}{|c|c|c|}
\hline Response & $\begin{array}{c}\text { Percentage of } \\
\text { respondents }(\%)\end{array}$ & Suggested cause of elephant decline in SWRA \\
\hline Poaching & 30 & $\begin{array}{l}\text { Poaching was at peak between } 2009 \text { and } 2016 \text { with the } \\
\text { majority of poached elephants being male adults } \\
\text { (approximately 95\%), sub-adult bulls/cows (5\%). The } \\
\text { existing herds of elephants were observed to be very } \\
\text { nervous and frightened, followed by a quick long-distance } \\
\text { movement when disturbed in an area or if any suspicious } \\
\text { sound is heard. }\end{array}$ \\
\hline Migration & 30 & $\begin{array}{l}\text { Seasonal movements to higher grounds and other areas in } \\
\text { search of forage and to avoid muddy areas during the rainy } \\
\text { season. Migration consisted of cyclical dispersal by } \\
\text { resident herds and long-distance migration to other } \\
\text { protected areas such as Chizarira and HNP. Local cyclical } \\
\text { migration consisted of movements from one side of the park } \\
\text { for few days such as moving from the Manyoni area to } \\
\text { Malundi ridge. Immigration of elephants into SWRA was } \\
\text { high during the dry season, from April to the end of } \\
\text { November whilst emigration was observed at the start of } \\
\text { each rain season. }\end{array}$ \\
\hline $\begin{array}{l}\text { Trophy } \\
\text { hunting }\end{array}$ & 8 & $\begin{array}{l}\text { Adult bulls were targeted including tuskless elephants thus } \\
\text { increasing pressure on the elephant population and reduce } \\
\text { recruitment in baby elephants. }\end{array}$ \\
\hline
\end{tabular}




\begin{tabular}{|l|l|l|}
\hline Settlement & 8 & $\begin{array}{l}\text { Population pressure and increase in demand for land for } \\
\text { farming, settlement along with the buffer and Manyoni area } \\
\text { resulted in illegal encroachment into the buffer zone and } \\
\text { more recently, the degazettement of part of the SWRA by } \\
\text { the government, hence habitat loss and fragment believed } \\
\text { to drive elephants away and killing of as part of controlling } \\
\text { human-wildlife conflict in these newly settled areas. }\end{array}$ \\
\hline $\begin{array}{l}\text { Climate } \\
\text { change }\end{array}$ & $\begin{array}{l}\text { Drying up of water sources and increase in average } \\
\text { temperatures and severe droughts in recent years resulting } \\
\text { in elephants moving to border areas in the Manyoni and } \\
\text { Binga Communal Areas Management Programme for } \\
\text { Indigenous Resources (CAMPFIRE) where surface water is } \\
\text { available in Malundi and Manyoni River. During the dry } \\
\text { season, the concentration of elephants around water holes } \\
\text { in SWRA used to be high in areas such as Ketsanga, } \\
\text { Siamlambo, Chenzembwe, and Chemhondoro springs and } \\
\text { pools along the Sengwa River. Persistent drought in recent } \\
\text { years and poor rains resulted in the premature drying-up of } \\
\text { water sources as early as June. }\end{array}$ \\
\hline
\end{tabular}

\section{Proposed management measures}

Ranger perceptions highlighted the need to intensifying patrols across Sebungwe landscape to increase ground coverage, suspend trophy hunting in SWRA, add more surface water by drilling boreholes, invent new elephant tracking technologies such as the use of GPS enabled collars, encourage and working with stakeholders for the establishment of community conservancy in adjacent previously buffer zones for the expansion of elephant habitats and providing incentives to local communities towards promoting stewardship and discourage elephant poaching (Table 2).

Table 2: A summary of ways to manage elephant populations in SWRA based on ranger knowledge and perception.

\begin{tabular}{|l|l|}
\hline Number & \multicolumn{1}{|c|}{ Ways to improve elephant population in SWRA } \\
\hline 1 & $\begin{array}{l}\text { Intensifying monitoring patrols throughout Sebungwe Landscape: The use of } \\
\text { Geographic Information System (GIS) and Global Positioning System (GPS) } \\
\text { technologies allow patrols to become more systematic, improving coverage and } \\
\text { efficiency in a way that causes would-be poachers to think twice or risk being } \\
\text { arrested. This can be done through the adoption of 'smart patrol' techniques, such } \\
\text { as Management Information System Technology (MIST) and the Spatial } \\
\text { Monitoring and Reporting Tool (SMART), in which patrolling rangers collect and } \\
\text { record data on signs of poaching activity that can be used as intelligence and be } \\
\text { used to gauge wildlife distribution for patrol and management purposes. }\end{array}$ \\
\hline
\end{tabular}




\begin{tabular}{|l|l|}
\hline 2 & $\begin{array}{l}\text { Spot hunting which was introduced in } 2003 \text { on an experimental basis needs to be } \\
\text { terminated. This will allow elephants and other animals to move back to the area. }\end{array}$ \\
\hline 3 & $\begin{array}{l}\text { With severe droughts, some waterpoints dried up and there is a need to drill } \\
\text { boreholes and scoop water pans to allow permanent water throughout the year. } \\
\text { Surface lures water-dependent animals and reduce the distance moved to search } \\
\text { for water from forage sites. }\end{array}$ \\
\hline 4 & $\begin{array}{l}\text { Improve monitoring of elephant dispersal through GPS collars so that seasonal and } \\
\text { daytime movement is established. This helps to track elephant movement and } \\
\text { improve their habitats, corridors and water provisioning and it increases } \\
\text { monitoring of their movement. }\end{array}$ \\
\hline 5 & $\begin{array}{l}\text { The establishment of community conservancy in adjacent communities will help } \\
\text { to increase habitat size and reduce fragmentation due to illegal settlement in and } \\
\text { along the SWRA boundary. This will also help to re-establish the buffer zone } \\
\text { where elephants and other animals previously occupy. }\end{array}$ \\
\hline 6 & $\begin{array}{l}\text { Community benefits: Benefits provided by SWRA from employment and revenue } \\
\text { sharing from the sale of park products are perceived to be inequitable to adjacent } \\
\text { communities. Increasing incentives for stewardship, mitigating against human- } \\
\text { wildlife conflict, and strengthening disincentives for poaching were all sighted as } \\
\text { ways to a comprehensive response to reducing elephant and other animal poaching } \\
\text { in SWRA. }\end{array}$ \\
\hline
\end{tabular}

\section{DISCUSSION}

Our results from ranger-based knowledge and perceptions emphasised anthropogenic factors as the key contributor to elephant dynamics in SWRA. There was a general suggestion by participants on major factors affecting elephant population dynamics in SWRA. Participants highlighted that SWRA proximity to communal areas may have resulted in complex encroachment by settled people. Studies have shown that human presents and settlements close to protected areas influence elephant movements (Chinoitezvi, 2017; Mpakairi et al., 2019), and with the unavailability of physical barriers to restrict elephant movement, elephant populations can be compromised through poaching, habitat deterioration, migration and human encroachment. Natural death due to environmental factors can also affect the elephant population in a protected area (Gandiwa et al, 2016; Ogutu et al, 2011; Mpakairi et al., 2019).

\section{Human Settlement and Encroachment}

Habitat loss through the opening of agricultural lands caused by settlement through the promulgation of statutory instrument 47 of 2014 and illegal hunting in SWRA may disrupt and destroy elephant societies (Mpakairi et al., 2019). In turn, these disruptions can limit the adaptive value of animal social relationships or alter the structure of genetic variation in animal populations and thus resulting in elephant migration and or mortalities which may negatively affect its population (Foley, 2002). Dudley (1999), reported that elephant dynamics within the 
semi-arid woodlands landscapes including in SWRA are modulated by human influences on elephant population density and distributions. The findings were supported by Mpakairi et al (2019), who highlighted that human settlements drive elephant movements in the Sebungwe region in their study carried out in the Kavango-Zambezi Transfrontier Area (KAZA).

Presently, elephant conservation is faced with many challenges. In many areas, a major threat to elephants is the increasing proximity and in most areas, actual encroachment by human settlements and activities into SWRA (Ranger observation). The human population has continued to increase and thus exert great pressure on the limited natural resource base. Consequently, conservation areas that were once large and surrounded by adequate buffer zones have increasingly been fragmented and the compressed wildlife populations, leading to overcrowding and habitat degradation. This may have resulted in competition for resources and thus may lead to intense human-elephant conflicts around SWRA (Dudley, 1999). In SWRA elephants are now confined to a small area and the previous buffer zones which used to help stabilise the protected area now occupied with very limited parches still standing (Ranger observations).

The only prevailing model of interaction between elephants and humans (Parker and Graham 1989) proposes that elephant distribution is the inverse of human distribution and that elephant abundance is dependent upon human abundance, based on relative densities at a given scale. This was supported by Mpakairi et al., (2019), who observed that human settlement drives the potential distribution of elephants in the Sebungwe Region (test AUC $=0.95$ ), and patches from the model were on average $<1.5 \mathrm{~km}^{2}$. This is supported by ranger based knowledge and perception who outlined that recent settlements and encroachment by local communities into the buffer zone could have contributed to elephant decline in SWRA.

\section{Elephant Trophy Hunting and Poaching}

In SWRA and other areas in Zimbabwe, hunting selectively removes older bulls with large tusks (Poole and Dobson, 1998) and recently, tuskless elephants have been targeted. Such is also the case with consequences of these effects for elephant societies (Gobush and Mutayoba, 2008). Poaching from 2008 to 2016 was on the rise in several elephant populations(Wittemyer et al., 2014; Dunham, 2008). In SWRA, rangers highlighted that between 2010 and 2016, poaching dominated all other mortality forms (Figure 3 below). Wild elephants are also facing new threats from habitat loss and human-wildlife conflict exposing them to illegal killing and elimination as a mitigation measure by relevant authorities, which is a direct response to increasingly constrained smaller areas where there is growing contact with humans. (Gobush and Mutayoba, 2008). 


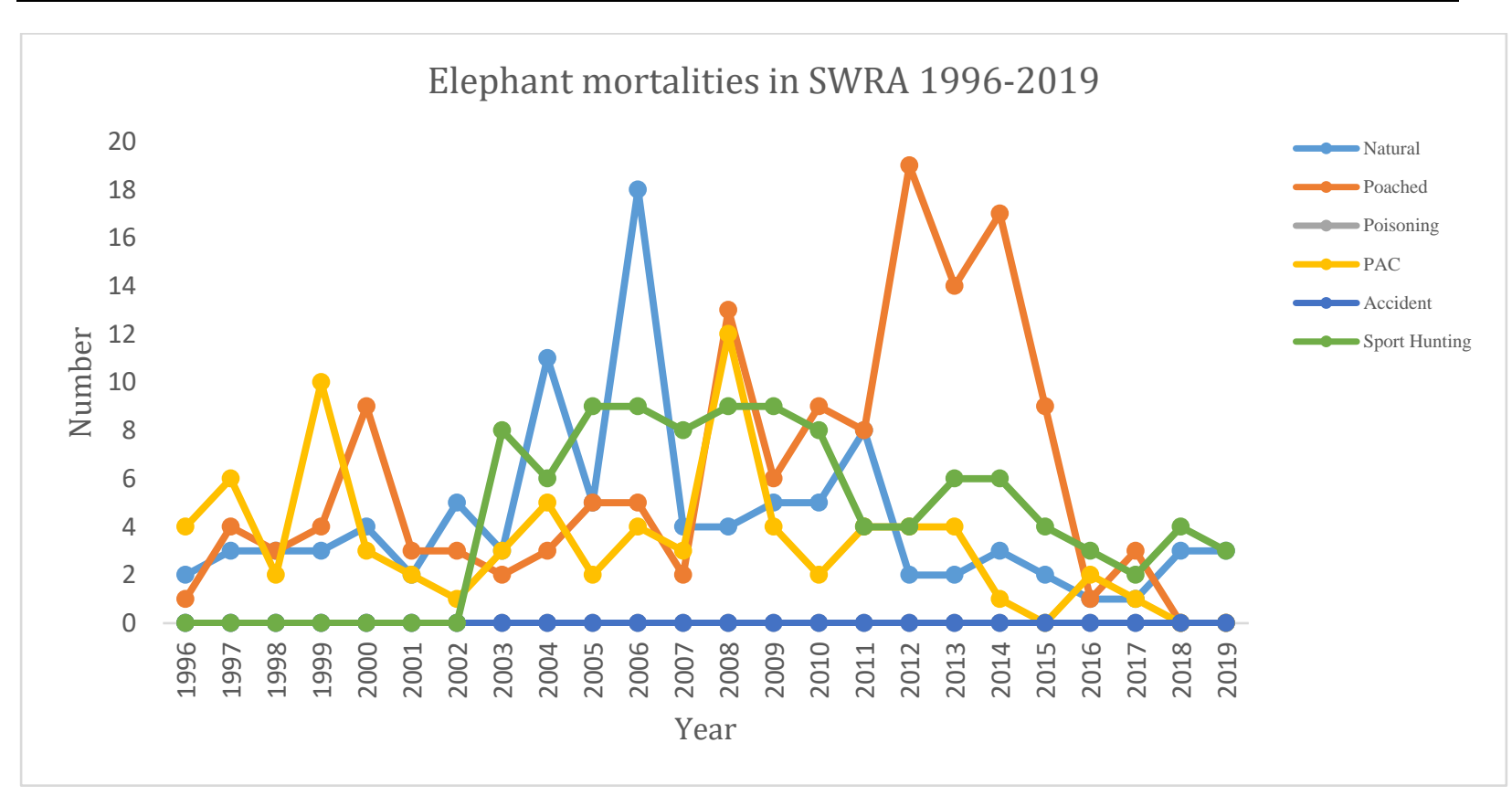

Figure 3: Trend in elephant mortalities based on different methods from 1996 to 2019. Poaching and natural mortalities have the highest numbers, with death due to accidents maintained at zero.

Poaching removes older animals and kin from elephant populations, with important consequences for females and males (Gobush and Mutayoba, 2008). For females, the loss of important social partners may decrease female fitness, which may influence population growth rates. For males, poaching seems to increase reproductive skew, which may increase the rate at which genetic diversity is lost from natural populations (Archie and Chiyo, 2011; Njumbi, 1993). Station records indicate that $95 \%$ of poached elephants in SWRA were adult bulls with the remaining $5 \%$ being sub-adult bulls or old cows. The literature highlighted that reducing the number of breeding males will decrease the effective population size of elephant populations and increase the rate at which genetic diversity is lost (Archie and Chiyo, 2011 ).

The level of poaching, although it appears to have decreased over the last 4 years in SWRA, may have an impact on the demographic status by selectively targeting mature adults. The ranger knowledge and perception coincided with the results of an aerial survey which indicated a major decline in elephant bulls while cow populations were constantly increasing over the years in SWRA (Table. 3). 
Table 3: Trends in elephant population density of bulls and cows following an aerial survey of 1997, 2002 and 2014.

\begin{tabular}{|l|l|l|l|l|l|l|l|l|l|}
\hline \multicolumn{2}{|c|}{ Population estimates and statistics for elephants in SWRA } \\
\hline \multirow{3}{*}{ Bulls } & Year & Estimate & $\begin{array}{l}\text { No. } \\
\text { Seen }\end{array}$ & Variance & \%CI & $\begin{array}{l}\text { Lower } \\
\text { CL }\end{array}$ & Upper CL & Density \\
& 2014 & 90 & 17 & 1165 & 81.3 & 17 & 163 & 0.24 \\
& 2002 & 183 & 30 & 18974 & 170.3 & 0 & 495 & 0.49 \\
& 1997 & 229 & 53 & 2528.5 & 45.9 & 123.7 & 333.5 & 0.6 \\
\hline Cows & 2014 & 768 & 145 & 94866 & 86.0 & 145 & 1429 & 2.06 \\
& 2002 & 738 & 121 & 203027 & 138.1 & 0 & 1757 & 1.97 \\
& 1997 & 574 & 133 & 33071.1 & 66.1 & 194.2 & 952.9 & 1.5 \\
\hline
\end{tabular}

(Source: Zimbabwe National Elephant Survey Reports 1997, 2001, 2014).

75 per cent of the participants indicated that frequent encounters with elephant sightings during patrols was biased towards cows and occasionally subadult bulls in family herds. Also, 50 per cent of the participants indicated that earlier in 2009, encounters with large bulls were equally the same with cows during which poaching was very low in SWRA.

Respond from participants indicated that the quota allocated for trophy hunting was high and argued the need to stop trophy hunting in SWRA. Rangers who participated in trophy hunting admitted there was a significant decrease in the trophy quality of elephants. This was supported by findings from Ngorima et al, (2015) who did an analysis on the trophy quality from 2003 to 2013 on elephants in SWRA and reported a significant decrease in trophy quality for elephants and further indicated that the hunting success rate declined with each passing hunting season. Analysis of annual trophy hunting also indicated poor utilisation of allocated trophy quota with constant review downwards. Trophy hunting of bull elephants was almost 90 per cent successful prior to 2009. However, since then, it was reduced to almost 10 per cent success with only hunting of tuskless elephants being successful.

However, the decline in trophy quality could not be attributed directly to the decline in the elephant population in SWRA since the density of elephant cows increased from 1.5 to 2.06 in 1997 and 2014 respectively (Dunham et al, 2015). Thus selective hunting (Both spot hunting and poaching) could have contributed to the decline in adult elephant bulls in SWRA from the participant's perception. However, indirectly trophy-hunting may negatively affect breeding herds and thus affect the elephant population according to Ngorima, (2017) in his paper "Retrospect of trophy hunting now and the future in SWRA".

The decline in the success rate in trophy hunting for elephants could have also been affected by trophy hunting taking place in adjacent hunting areas (Ranger observation). SWRA shares elephants with other adjacent areas and this means the same elephant herds were targeted for trophy hunting and poaching in these adjacent areas. Ranger knowledge and perceptions highlighted the pressure on elephant bull hunting was multifaceted for spot hunting and illegal poaching (Ranger observations). 


\section{Climate Change}

Ranger based knowledge from the survey support the findings by Kupika et al, (2018) who highlighted that common effects of climate change on wildlife include changes in life-history events, effects on demographic rates and reduction in population size as well shifts in species distributions. Climate change poses direct and indirect effects on wildlife (Texeira and Baldi, 2012) through changes in fitness, survival and reproductive success (Milligan and Holt, 2009). In semiarid ecosystems, climatic changes in frequency and severity of droughts are likely to exacerbate the effects of drought on forage availability, which can serve to regulate reproduction and offspring recruitment among ungulates (Koons et al., 2012). Forrest et al., (2012) highlighted that climate change is likely to affect the persistence of elephants through habitat shifts, loss and fragmentation supporting the observation from ranger knowledge and perception.

Thus, climate-induced extreme events could have also threatened the survival of elephants in SWRA through reduced surface water and drying up of springs and the recent increase in temperature. Chamaille and Fritz, (2006) noted that climate change is predicted to affect both the mean annual rainfall and its seasonal distribution over the African continent. Thus, climate warming has the potential to directly affect wildlife resources through shifts in onset and duration of rainy seasons and drought on wildlife species, reduction in species distribution ranges, alteration in abundance and diversity of mammals, changes in calving and population growth rates, changes in juvenile survival of most ungulates (Chidumayo et al., 2011). Temperature and rainfall display complex temporal variations changing from place to place across the earth. These key climatic factors determine plant productivity and hence, animal food availability (Tokolyi and Schmidt 2014). Rainfall controls primary production (Chamaille and Fritz 2006) and ungulate grazer populations across the African savannah.

Rainfall in SWRA is characterised by monthly and intra-annual variability with a mean annual rainfall of $612 \mathrm{~mm}$. Rainfall variability has a distinct effect on the primary productivity of the area and hence, the wildlife that it can support. Apart from seasonal drying up, the quantity and quality of water at some sources have changed (Ranger observations, 2015) probably due to prolonged drought periods. For example, participants indicated that some springs such as Kamashaboya and Sijamba Spring which used to provide water for wildlife had in recent years dried up due to severe droughts experienced in recent years and may have an impact on the elephant population in SWRA and elsewhere.

Rainfall also varies at SWRA and this could affect the abundance and distribution of elephants elsewhere. An analysis of the annual rainfall data for SWRA shows a high of over $1000 \mathrm{~mm}$ and a low of slightly below 190mm in the 1996/1997 and 2012/2013 annual rain seasons. Large herbivores, in particular, elephants, could be under threat from periodic droughts. Noticeable changes in large mammal populations in the riverine woodlands and adjacent areas due to drought have been observed along Sengwa, Lutope and Manyoni rivers. Ranger knowledge and perception supported the findings by Tafangenyasha et al., (2016) that SWRA is a semiarid ecosystem with low and regular rainfall, high evapotranspiration and cyclical droughts. High evapotranspiration mean soils dry up quickly reducing the amount of water available for plants as well surface water. Some rise in local temperatures has been noted at the Institute with current average temperatures over 55 years recording $26.3^{\circ}$ Celsius (SWRA Metrological record). However, this shows a rise in temperature since 1965 when average temperatures were recorded to average $22.2^{\circ}$ Celcius (Torrance, 1965; Guy, 1979). 
Drought-related mortality of elephants has also been observed in SWRA in 1994-1995. Loveridge., (2006) revealed that high-density aggregations of elephants around limited water sources during the dry season in HNP may result in the depletion of local food resources. Additionally, elephant herds were forced to travel long distances between water and forage during which the elephant calves die (Loveridge et al., 2006).

\section{Migration}

Ranger knowledge indicated that SWRA elephants appear to show a wet season dispersal pattern, moving outside the central area of the study area to the periphery or to adjacent parks (end November through to April each year). These movements are believed necessary to avoid low laying muddy areas which affect their movement. Partial movement on elephants had been reported elsewhere and was noted to be influenced by some environmental variables (Purdon et al., 2018)

The SWRA elephants were reported to exhibit a pattern common to many other African elephant populations: a wet season migration, and a dry season concentration around permanent water sources (Griffiths, 1975). The SWRA elephants maintain their core home range in the park but execute frequent and short migrations to the Chizarira, Campfire and Chirisa (Ranger observation) searching for safe areas and water as well forage during the dry season.

A characteristic of the African savanna ecosystem is the spatial and temporal variation in resource availability due to periodic and irregular rainfall. This variation forces savanna wildlife to move to where food and water can be obtained (Mduma et al, 1999). When key essentials for survival are inadequate migration may become a successful strategy for coping with resource scarcity in highly seasonal environments. Response from participants indicated that the seasonal migration of elephants could have been attributed to these factors.

Participants also suggested migration in elephant bulls which coincided with hunting seasons. Although hunting season becomes very active between May and October each year, it was noted during this period, sightings of adult bulls everywhere were rare. At the start of the season, elephant bulls could move out of the area. Bull migration in relation to first hunts since poaching peaked from 2009 to 2016 (Ranger observation).

Even though migration was mentioned as a factor contributing to elephant decline in SWRA, participants admitted that it was difficult to ascertain the destination although this can be verified through evidence of the heavy flocking-in of large herds of elephants soon after the wet season. Some participants highlighted that during the wet season there was a time when elephants were not seen for days. The fact was validated through law enforcement reports where it was noted that from 2009, between January and the end of March recording of elephants sighting was very low. In SWRA, wet season migration has also been attributed to poaching to some extent during the rainy season. The poaching of elephants in SWRA was noted to be significant during the wet season (Chinoitezvi, 2017). Elephants had been observed to avoid their previous wet season territories, maybe because of the constant disturbance by illegal hunters who target elephants in thick areas when they will be avoiding low-lying muddy sites (Ranger observation). In recent years, rangers indicated low sightings of elephants in the northern side of the park especially in previously known poaching hotspots such as in Musamba Jesse and upper Samapakwa ridge. 
Rangers suggested that where poaching occurs, the elephant herds targeted regularly hear gunshots, encounter poachers and elephant carcasses and witness the death of conspecifics, including close associates and family members and as such, savannah elephants alter their behaviour when exposed to these threats; they immediately shift to more nocturnal activity patterns and increase flight behaviour as well, migrating to safer areas (Graham et al., 2009). In order to engage in risky behaviour such as crop-raiding, elephants wait until darkness falls, and avoid moonlit nights, before leaving secure areas (Galanti et al, 2006; Van Aarde et al 2007) into the communal area searching for forage and water, the case of Malundi water point adjacent to SWRA.

Even though the 2014 Aerial survey highlighted massive elephant decline in Sebungwe, Rangers expressed possible sources of bias that could have resulted in poor sightings of elephants in SWRA. During the census sighting choice of survey technique, climatic conditions and vegetation cover may have impacted the results. For more accurate results, all participants proposed that data should be collected by a wildlife management authority using standardised methods for collecting, recording and analysing data which also supports the ideas of Craig, (2012) and Hedges and Lawson, (2006). They recommended combining data from different types of surveys including data from patrol reports in estimating elephant population in SWRA. Seasonal and cross-boundary movements of elephants were considered as one factor that could have affected elephant sightings in SWRA. Ranger observations also suggested an increase in search effort during aerial counts determine the elephant carcass densities (no. $/ \mathrm{km}^{2}$ ) in SWRA, supporting suggestion by Dunham et al, (2015) and Griffiths, (1978). The Search effort of 15 for SWRA was suggested very low and could have contributed to the underestimation of the elephants in the area.

In a nutshell, Rangers admitted a marginal decline in elephant population in SWRA and suggested improvement in law enforcement, surface water, engage local adjacent communities, suspend trophy hunting and increase habitat size by assisting communities to form community conservancies. New technologies to identify individual animals, follow their movements, identify them, locate them and assess the status of their habitats remotely have been suggested for better, faster, and cheaper approaches in monitoring elephant dispersal and control poaching in SWRA. Rangers suggested that this can be strengthened by law enforcement, increasing awareness and environmental education, and developing mechanisms to reduce human-wildlife conflicts to further minimising illegal hunting activities. This suggestion supports findings in South East Low Veld, Zimbabwe by Gandiwa, (2011) who indicated the need to engage local communities in law enforcement activities.

\section{Implications to Research and Practice}

The use of Geographic Information System (GIS) and Global Positioning System (GPS) technologies can allow patrols to become more systematic, improving coverage and efficiency in a way that causes would-be poachers to think twice or risk being arrested. Rangers encouraged the adoption of 'smart patrol' techniques, such as the Spatial Monitoring and Reporting Tool (SMART), in which patrolling rangers collect and record information on signs of poaching activity that can be used as intelligence. Another implication is to establishing community engagement by improving livelihoods. Understanding the impact of poaching on affected populations, and engaging with local communities on enforcement activities, can both facilitate a greater understanding and support for local law enforcement efforts, as well as promote intelligence-led activity. The pivotal role of local communities in efforts to halt 
projects can be initiated by SWRI for local communities to benefit from leaving with the resources as well supporting locals in establishing conservancy areas, hence increasing elephant habitat sizes and support from adjacent communities.

\section{CONCLUSIONS}

Our survey results reveal patterns of elephant fluctuations concerning the effects of poaching, migration, climate change and human activities on elephant social relationships based on ranger knowledge and perceptions. Poaching and trophy hunting may have disrupted elephant organisation by removing older animals and kin, which can limit the adaptive value of female relationships. In this study, rangers disputed the method used for the 2014 National Elephant Survey as well as the timing of the survey sighting which observed changes in elephant behaviour in occupying thick bushes and fewer activities during the day to avoid humans. Elephant bulls were noted to decrease over the years with a density of 0.6 to 0.49 and 0.24 per $\mathrm{km}^{2}$ from 1997, 2002 and 2014 respectively and was attributed to selective hunting from ranger perception. Cow density, however, significantly increased during the same time. Human settlements were also suggested to have caused result migration to adjacent protected areas such as Chizarira, Hwange National Park as well as occupying other safer undisturbed habitats. Participants highlighted the need to intensify patrols throughout Sebungwe Landscape by investing in integrated technologies such as the use of Unmanned Aerial Vehicles (UAV) together with the use of Spatial Monitoring and Reporting Tool (SMART Technology), suspend trophy hunting in SWRA to restore the social relationship between elephant herds and reduce nervousness, improve game water provisioning and improve technology to monitor elephant seasonal dispersal. Proper land-use planning and development of community conservancy, buffer zones as well compatible land use is recommended to maintain elephant habitat in SWRA.

\section{Future research}

Future research should focus on establishing the impact of poaching on the elephant population and movement patterns across the landscape. A study on the impact of multiple anthropogenic and natural factors influencing elephants and other large herbivore populations is recommended as a way to monitor the trend over time.

\section{Acknowledgements}

We thank all the respondents who participated in this study, the SWRA, CSA and ex-station staff for their immense contribution through data collection and for their interest to attend to the questionnaire. This research was supported by the Zimbabwe Parks and Wildlife Management Authority, Chief Ecologist Terrestrial Mrs R. Chikerema-Mandisodza. We are also grateful to an anonymous reviewer for the valuable comments and suggestions. 


\section{REFERENCE}

[1]. Elizabeth A. Archie Patrick I. Chiyo (2011). Elephant behaviour and conservation: social relationships, the effects of poaching, and genetic tools for management.

Retrieved from https://doi.org/10.1111/j.1365-294X.2011.05237.x

[2]. Beale, C. M., Hauenstein, S., Mduma, S., Frederick, H., Jones, T., Bracebridge, C., Kohi, E. M. (2018). Spatial analysis of aerial survey data reveals correlates of elephant carcasses within a heavily poached ecosystem. Biological Conservation. Https://doi.org/10.1016/j.biocon.2017.11.016

[3]. By Lara S. Foley. (2002). The Influence of Environmental Factors and Human Activity on Elephant Distribution in Tarangire National Park, Tanzania. International Institute For Geo-Information Science And Earth Observation Enschede, The Netherlands.

[4]. Chamaille-Jammes S, Fritz H, Murindagomo. F. (2006). Spatial patterns of the NDVIrainfall relationship at the seasonal and interannual time scales in an African savanna. International Journal of Remote Sensing., 27, 185-200.

[5]. Chamaillé-Jammes S, Fritz H, Murindagomo. F. (2007). Climate-driven fluctuations in surface water availability and the buffering role of artificial pumping in an African savanna: Potential implication for herbivore dynamics. Austral Ecology. 2007;32:740748, 32, 740-748.

[6]. Emmanuel Chidumayo, David Okali, Godwin Kowero, Mahamane Larwanou (2011). Climate Change and African Forest and Wildlife Resources. Nairobi, Kenya:

[7]. Chinoitezvi Exeverino. (2017). Southern African Wildlife Management Association (SAWMA) Annual Conference: 10-14, September 2017. Spatial and Temporal Patterns of Illegal Hunting of Four Wild Herbivores in Sengwa Wildlife Research Area (SWRA), Zimbabwe.

[8]. Cumming, D. H. M. (1975). A field study of the ecology and behaviour of warthog. In Museum Memoir No.7, Trustees National Museum of Rhodesia, Salisbury.

[9]. Douglas-Hamilton, I., and Burrill, A. (1991). Using elephant carcass ratios to determine population trends. African Wildlife: Research and Management (International Council of Scientific Unions), 98-105.

[10]. Douglas-Hamilton, I., and Hillman, A. K. K. (1981). Elephant carcasses and skeletons as indicators of population trends. In Low-Level Aerial Survey Techniques, ILCA Monograph 4 (ILCA), 131-142.

[11]. Dudley, J. P. (1999). Final report of research findings: Elephant and vegetation research project Final report of research findings: Elephant and.

[12]. Dunham, K. M. (2008). Detection of anthropogenic mortality in elephant Loxodonta africana populations: a long-term case study from the Sebungwe region of Zimbabwe. Oryx, 42, 36-48.

[13]. Gandiwa, Edson; Heitkönig, I.M.A.; Eilers, Paul H.C.; Prins, Herbert H.T. (2016). Rainfall variability and its impact on large mammal populations in a complex of semiarid African savanna protected areas. Tropical Ecology, 57(2), 163-180.

[14]. Jessica L.Forrest., Eric Wikramanayake., RinjanShrestha., GopalaAreendran., KinleyGyeltshen., Aishwarya Maheshwari., Sraboni Mazumdar., Robin Naidoo., Gokarna JungThapa., Kamal Thapa (2012). Conservation and climate change: Assessing the vulnerability of snow leopard habitat to treeline shift in the Himalaya. Biological Conservation., 150, 129-135. 
[15]. K S Gobush, B M Mutayoba, S K Wasser (2008). Long-term impacts of poaching on relatedness, stress physiology, and reproductive output of adult female African elephants. Conservation Biology, 22, 1590-1599.

[16]. Guy, P. R. (1989). The influence of elephants and fire on Brachystegia-Julbernadia woodland in Zimbabwe.

[17]. James. F. Quinn; Susan. P. Harrison. (1988). Effects of habitat fragmentation and isolation on species richness: Evidence from biogeographic patterns. Oecologia, 75, 132-140.

[18]. K.M. Dunham, C.S. Mackie, G. Nyaguse. And C. Zhuwau. (2015). Aerial survey of elephants and other large herbivores in the Sebungwe (Zimbabwe): 2014. April 2015, revised October 2015. Great Elephant Census. A Paul G. Allen Project in Partnership with the Zimbabwe Parks and Wildlife Management Authority.

[19]. Koons D.N, Terletzky P, Adler PB, Wolfe ML, Ranglack D, Howe FP, Hersey K, P., \& W, du T. J. (2012). Climate and density-dependent drivers of recruitment in plains bison. Journal of Mammalogy, 93, 475-481.

[20]. Levina E, T. D. (2006). Adaptation to Climate Change: Key Terms. Organisation for Economic Co-operation and Development; 2006. P. 1-25.

[21]. A. J. Loveridge J. E. Hunt F. Murindagomo D. W. Macdonald (2006). Influence of drought on predation of elephant (Loxodonta africana) calves by lions (Panthera leo) in an African wooded savannah.No Title. Journal of Zoology., 270, 523-530.

[22]. Mapaure, I. (2001). The influence of elephants and fire on the structure and dynamics of miombo woodland in Sengwa Wildlife Research Area, Zimbabwe. PhD Thesis, University of Zimbabwe, Harare.

[23]. Mapaure, I. And Campbell, B.M. (2002). Changes in Miombo woodland cover in and around Sengwa Wildlife Research Area, Zimbabwe, in relation to elephants and fire. African Journal of Ecology, 40, 212-219.

[24]. Simon A. R. Mduma A. R. E. Sinclair Ray Hilborn (1999). Food regulates the Serengeti wildebeest: a 40-year record. J. Anim. Ecol, 68, 1101-1122.

[25]. Stuart R. Milligan, William V. Holt and Rhiannon Lloyd (2009). Impacts of climate change and environmental factors on reproduction and development in wildlife. Philosophical Transactions of the Royal Society of London. Series B, Biological Sciences., 364, 3313-3319.

[26]. Mpakairi, K. S., Ndaimani, H., \& Kuvawoga, P. T. (2019). Human settlement drives African elephant (Loxodonta africana) movement in the Sebungwe Region, Zimbabwe.

[27]. Ngorima Patmore. (2017). Trophy Hunting Anxiety at Sengwa in Retrospect Now and the Future. International Journal of Environmental Sciences and Natural Resources, 4(3). Retrieved from doi: 10.19080/IJESNR.2017.04.5555638

[28]. Ngorima Patmore (2015). Analysis of trends on trophy quality of African elephant, lion, buffalo and stakeholders perceptions in Sengwa Wildlife Research Area, Zimbabwe from 2003 to 2013. Ttps://Www.Researchgate.Net/Publication/286342435.

[29]. Njumbi, J. S. (1993). Effects of Poaching on the Population Structure of Elephants in Meru National Park. Unpublished msc. Thesis, Moi University.

[30]. Norton-Griffiths. (1978). Counting Animals, Handbooks on techniques currently used in African wildlife ecology. No.1, African Wildlife Leadership Foundation.

[31]. Norton-Griffiths, M. (1975). The numbers and distribution of large mammals in Ruaha National Park, Tanzania. East African Wildlife Journal, 13, 121-140. 
[32]. J. O. Ogutu H.-P. Piepho H. T. Dublin N. Bhola R. S. Reid (2008). Rainfall influences ungulate population abundance in the Mara-Serengeti ecosystem. Journal of Animal Ecology 77: 814-29., 77, 814-829.

[33]. J. O. Ogutu N. Owen-Smith H.-P. Piepho M. Y. Said (2011). . Continuing wildlife population declines and range contraction in the Mara region of Kenya during 19772009. Journal of Zoology., 285: 99-109.

[34]. Olga L. Kupika, Edson Gandiwa, S. K. And, \& Nhamo, G. (2018). Impact of Climate Change and Climate Variability on Wildlife Resources in Southern Africa: Experience from Selected Protected Areas in Zimbabwe. intechopen. Retrieved from http://dx.doi.org/10.5772/intechopen.70470

[35]. Norman Owen-Smith, Darryl R. Mason and Joseph O. Ogutu (2005). Correlates of survival rates for 10 African ungulate populations: Density, rainfall and predation. The Journal of Animal Ecology. 2005;74:774-788, 74, 774-788.

[36]. P.R. Guy, Z. Mahlangu. And H. Charidza. (1979). Phenology of some trees and shrubs in the Sengwa Wildlife Research Area, Zimbabwe-Rhodesia. Southern African Journal of Wildlife Research, 9, 47-54.

[37]. Poole, J., and Dobson, A. P. (1998). Conspecific aggregation and conservation biology. Behavioural Ecology and Conservation Biology, T. Caro, Ed. (Oxford University Press), 193-208.

[38]. Purdon, A., Mole, M.A., Chase, M.J., and van Aarde, R. J. (2018). Partial migration in savanna elephant populations distributed across southern Africa. Sci. Rep. 8, 11331., 8, 11331.

[39]. R.D. Taylor, D. H. M. Cumming. And C. M. (1991). Multispecies animal production systems projects: Aerial census of elephants and other large herbivores in the Sebungwe 1991. WWF. A Zimbabwe department of national parks and wildlife management collaborative project.

[40]. Shrader, A. M., Stuart. L. Pimm. \& Rudi. van Aarde. (2010). Elephant survival, rainfall and the confounding effects of water provision and fences. Biodiversity and Conservation, 19, 2235-2245.

[41]. Tafangenyasha C, Muchachavangwa S, Mvulah B, Makausi F, G., \& S, Harrison A, Parakasingwa L, Chinoitezvi E, M. G. (2016). Transient feedback in woody vegetation response in aftermath of elephant culling history at Sengwa Wildlife Area, Zimbabwe. International Journal of Wildlife and Endangered Species Conservation (IJWESC), $1(1), 22-36$.

[42]. Texeira Mrcos, Baldi German, Paruelo. Jose. (2012). An exploration of direct and indirect drivers of herbivore reproductive performance in arid and semi-arid rangelands by means of structural equation models. Journal of Arid Environment. 2012;81:26-34, $81,26-34$.

[43]. Shamiso Mhiripiri \& Donald Mlambo (2020). The effects of land use and microsite availability on early seedling recruitment of Acacia tortilis (synonym: Vachellia tortilis) in a southern African savanna. International Society for Tropical Ecology. Https://doi.org/10.1007/s42965-020-00128-z.

[44]. Tokolyi J, Schmidt J, B. Z. (2014). Climate and mammalian life histories. Biological Journal of the Linnean Society.;111:719-736, 111, 719-736.

[45]. Torrance, J. D. (1965). The temperatures of Rhodesia. In: Rhodesia, its Natural Resources and Economic Development. (ed. M.O. Collins). M.O. Collins, Salisbury. 
African Journal of Environment and Natural Science Research

ISSN: 2689-9434

Volume 4, Issue 4, 2021 (pp. 43-60)

www.abjournals.org

[46]. H Wild; Luis Augusto Grandvaux Barbosa (1967). Vegetation map of the Flora Zambesiaca Area, Supplement to the Flora Zambeziaca (ED. H.Wild \& A. Fernandes). M.O. Collins (Pvt)Ltd., and Government Printer, Salisbury.

[47]. Wittemyer, G., J. M. Northrup, J. Blanc, I. Douglas-Hamilton, P. Omondi, and K. P. B. (2014). Illegal killing for ivory drives global decline in African elephants. Proceedings of the National Academy of Sciences, 111, 1-5. 